Vol 10, Issue 11, 2017

\title{
EFFECT OF ARTHROSPIRA PLATENSIS AS A FOOD SUPPLEMENT AGAINST SODIUM FLUORIDE- INDUCED INTOXICATION ON SOFT TISSUES OF MALE WISTAR ALBINO RATS
}

\author{
RAVINDRA REDDY KANDULA ${ }^{1}$, NARASIMHA JAYAVEERA KORLAKUNTA², RAGHAVENDRA MITTA ${ }^{3 *}$
}

${ }^{1}$ Department of Pharmaceutics, PRRM College of Pharmacy, Kadapa-516003, Andhra Pradesh, India. ${ }^{2}$ Department of Chemistry, VEMU Institute of Technology, Pakala Kothakota - 517 112, Chittoor, Andhra Pradesh, India. ${ }^{3}$ Department of Pharmacology, CMR College of Pharmacy, Hyderabad - 501 401, Telangana, India. Email: mittargv@gmail.com

Received: 01 June 2017, Revised and Accepted: 19 July 2017

ABSTRACT

Objective: The objective of the present study was to explore the in vitro antioxidant and effect of hydroalcoholic extract of Arthrospira platensis (ASP) against sodium fluoride ( $\mathrm{NaF}$ )-induced toxic effects on soft tissues (heart, liver, and kidney).

Methods: In vitro antioxidant activity was assessed using 1,1-diphenyl-2-picrylhydrazyl radical scavenging, 2,2'-azino-bis(3-ethylbenzothiazoline6-sulphonic acid) radical scavenging, metal chelation, total antioxidant and reducing power assays, and total flavonoid and phenol content. In this study, 36 male Wistar albino rats were divided into six groups of six animals each. Animals were served as Group I - normal control, Group II - toxic control, and Groups III, IV, and V - treatment groups, which received hydroalcoholic extract of ASP at doses of 100, 200, and $400 \mathrm{mg} / \mathrm{kg}$ body weight (p.o), respectively. Group VI served as plant control received hydroalcoholic extract of ASP at a dose of $400 \mathrm{mg} / \mathrm{kg}$ body weight (p.o). All groups except Groups I and VI received NaF (100 ppm) through drinking water for 30 days.

Results: Results showed that intoxication of NaF caused significant elevation of serum biomarkers of the heart, liver, and kidney and altered tissue oxidative stress markers' levels. Administration of hydroalcoholic extract of ASP significantly normalized elevated serum levels of heart ( $\mathrm{p}<0.001$ ), liver $(p<0.001, p<0.05)$, and kidney biomarkers $(p<0.001)$. Decrease in lipid peroxidation and increase in reduced glutathione and catalase enzyme levels in a dose-dependent manner were observed in soft tissues $(\mathrm{p}<0.001, \mathrm{p}<0.01$, and $\mathrm{p}<0.05)$.

Conclusion: The study revealed that ASP has good antioxidant and mitigative action against NaF intoxication on soft tissues.

Keywords: Arthrospira platensis, Oxidative stress, Serum biomarkers, Sodium fluoride.

(C) 2017 The Authors. Published by Innovare Academic Sciences Pvt Ltd. This is an open access article under the CC BY license (http://creativecommons. org/licenses/by/4. 0/) DOI: http://dx.doi.org/10.22159/ajpcr.2017.v10i11.20382

\section{INTRODUCTION}

Fluoride ion is one of the highly reactive, strongly electronegative ions which belong to halogen group. It is derived from fluorine gas which is not available in free form in the nature but chemically combines with other elements to exist as ionic forms such as sodium fluoride (NaF), hydrogen fluoride, and aluminum fluoride. It abundantly, hastily, and submissively crosses into to the intestinal mucosa to interfere various major metabolic processes of the living system after oral consumption through drinking water [1]. The natural source of fluoride ion is soil rock, and other chief sources include beverages, food, medicines, dust in air, and various other industrial processes [2].

Globally, around 25 nations' (200 millions of people) ground water is highly contaminated with fluoride and is at a risk of fluorosisrelated health problems [3]. In India, approximately 150,000 villages ( 65 millions of people) are at risk of fluorosis of various levels and have been reported as "fluoride levels above the noticeable limits (1.5 ppm)," particularly Andhra Pradesh, Telangana, Rajasthan, and Gujarat states are highly prone to fluorosis and related problems [4].

Fluoride provokes excessive formation of free radicals and might cause the imbalance between the production and function of enzymatic and non-enzymatic antioxidant levels [5]. The success rate for prevention and mitigation or treatment of fluorosis was limited to very few physicochemical (ion exchange or adsorbent techniques) and therapeutic methods [6].

Earlier research reports strongly suggested that natural diet with a rich source of ascorbic acid, minerals, vitamins, and secondary metabolites effectively minimizes and recovers fluoride-induced health problems [7]. Arthrospira platensis (ASP) is widely and easily available edible material in the world. It is commonly called as super food which might be due to rich source of nutrients (proteins, vitamins, and minerals) and phytochemical constituents (alkaloids, phenols, and terpenoids). It was proved as antiviral and antimicrobial [8], hepatoprotective [9], nephroprotective [10], cardioprotective [11], antiobesity [12], and reduces dental plaque [13] edible material. Therefore, the purpose of present study is to find out the alleviatory effects of hydroalcoholic extract of ASP leaves against NaF-induced intoxication of soft tissues in male Wistar albino rats

\section{METHODS}

Collection and authentication of plant material

ASP freeze-dried powder was purchased from Parry Neutraceuticals, Division of EID Parry (India) Ltd, Chennai, Tamil Nadu, India, and authentication was done by Dr. Sunita Garg, Chief scientist, Raw Material Herbarium and Museum, Delhi (RHMD), CSIR-NISCAIR; Voucher specimens were stored in the department of Pharmacology, CMR College of Pharmacy, Hyderabad, Telangana, India.

Preparation of the extract

The ASP powder (100 g) was mixed with water:alcohol (30:70) in a round bottom flask and left for 7 days at room temperature with occasional shaking. After 7 days, the mixture was filtered with Whatman filter paper no. 1 . The filtrate was evaporated in vacuo using rotary flash evaporator. About $16 \%$ of semi-solid yield was obtained. The extract was stored at $4^{\circ} \mathrm{C}$ for further studies.

Experimental animals

Male Wistar albino rats (36) weighing in between 220 and $250 \mathrm{~g}$ were procured from Sai Thirumala Enterprises, Hyderabad, India. The animals were acclimatized for 10 days before starting the experiment. 
Rat feed was provided with water ad libitum and maintained a photoperiod of $12 \mathrm{~h}$ light/dark cycle. The study was completed as per the guidelines of CPCSEA, Government of India, after approval from IAEC (IAEC no: CPCSEA/1657/IAEC/CMRCP/PhD-15/40).

\section{In vitro antioxidant studies}

The 1,1-diphenyl-2-picrylhydrazyl (DPPH) radical scavenging activity, 2,2'-azino-bis(3-ethylbenzothiazoline-6-sulphonic acid) (ABTS) radical scavenging activity, metal chelating assay, total antioxidant activity, reducing power assay, total flavonoid content, and total phenol content were estimated as per standard protocol [14].

\section{Acute toxicity studies}

Acute toxicity study was performed according to the guidelines of OECD 425.

\section{Experimental design}

The dose of $\mathrm{NaF}$ was selected based on the previous research studies [15]. After 10 days of acclimatization period, the experimental animals were divided into six groups $(\mathrm{n}=6)$ as follows:

- Group I: The animals received drinking water for 30 days

- Group II: NaF (100 ppm) through drinking water for 30 days

- Group III: ASP extract at an oral dose of $100 \mathrm{mg} / \mathrm{kg}$ bw/day + NaF $(100 \mathrm{ppm})$ through drinking water for 30 days

- Group IV: ASP extract at an oral dose of $200 \mathrm{mg} / \mathrm{kg} \mathrm{bw} /$ day + NaF $(100 \mathrm{ppm})$ through drinking water for 30 days

- Group V: ASP extract at an oral dose of $400 \mathrm{mg} / \mathrm{kg}$ bw/day + NaF (100 ppm) through drinking water for 30 days

- Group VI: Plant control - ASP extract at an oral dose of $400 \mathrm{mg} / \mathrm{kg}$ bw/day for 30 days (p.o) alone.

At the end of the study, animals were fasted overnight and blood samples were collected from retro-orbital plexus. Blood samples were allowed to clot for approximately $1 \mathrm{hr}$ at room temperature and centrifuged at $2500 \mathrm{rpm}$ for 15 minutes to obtain the serum, used for estimation of various biochemical parameters such as lactate dehydrogenase (LDH), creatine kinase-MB (CK-MB), glucose, magnesium, serum glutamic oxalocetic transaminase (SGOT), serum glutamic-pyruvic transaminase (SGPT), total and direct bilirubin, total protein, albumin, total cholesterol (TC), triglycerides (TGs), high-density lipoprotein cholesterol (HDL-C), blood urea nitrogen (BUN), uric acid, and creatinine were estimated using coral kits and semi auto analyzer (Inkarp ES-100). In vivo antioxidant markers such as lipid peroxidation, reduced glutathione, and catalase were estimated as per standard protocols [16-18].

\section{Statistical analysis}

The values were expressed as mean \pm standard error of mean. The statistical analysis was carried out by one-way analysis of variance followed by post hoc Dunnett's test using GraphPad prism 5.0. The values were statistically significant at $\mathrm{p}<0.05$.

\section{RESULTS}

\section{In vitro antioxidant activity}

The inhibitory concentration $50 \%\left(\mathrm{IC}_{50}\right.$ ) values for $\mathrm{DPPH}$ radical scavenging activity were found to be 6.8 and $213.42 \mu \mathrm{g} / \mathrm{ml}$ for the standard Vitamin C and ASP extract, respectively. The $\mathrm{IC}_{50}$ values for ABTS radical scavenging activity were found to be 14.1 and $520 \mu \mathrm{g} / \mathrm{ml}$ for the standard Vitamin C and ASP extract, respectively. The $\mathrm{IC}_{50}$ values for metal chelation assay were found to be 76.19 and $320 \mu \mathrm{g} / \mathrm{ml}$ for the standard ethylenediaminetetraacetic acid and ASP extract, respectively. Total antioxidant activity was found to be $247.09 \pm 0.94 \mu \mathrm{g}$ Vitamin C equivalents per mg of plant extract. The reducing power ability was found to be $82.67 \pm 1.26 \mu \mathrm{g}$ Vitamin C equivalents per $\mathrm{mg}$ of plant extract. Total flavonoid content was found to be $60.67 \pm 0.08 \mu$ g quercetin equivalents per mg of plant extract, and total phenol content was found to be $110.00 \pm 0.02 \mu$ g gallic acid equivalents per $\mathrm{mg}$ of plant extract.

\section{Acute toxicity studies}

Acute toxicity studies of ASP showed well tolerance at $2000 \mathrm{mg} / \mathrm{kg}$ bw p.o. All the animals in the treatment groups were normal in alertness and behavior up to $72 \mathrm{hrs}$ of post-administration. No mortality was observed until completion of the study. Therefore, $1 / 20,1 / 10$, and $1 / 5$ of this test dose were selected as low $(100 \mathrm{mg} / \mathrm{kg})$, medium $(200 \mathrm{mg} / \mathrm{kg})$, and high $(400 \mathrm{mg} / \mathrm{kg})$ doses, respectively, for screening the protective effects against NaF-induced toxicity.

\section{Effect on serum biomarkers of the heart, liver, and kidney}

\section{Effect on $C K-M B$ and $L D H$}

Fluoride toxicity also elevates the levels of CK-MB and LDH enzymes by increase the formation of superoxide anions and hydroxyl radicals which cause oxidative damage to the cell membrane of myocardium. In the present study, high intake of fluoride increased the blood serum levels of CK-MB and LDH of Group II $(p<0.001)$ when compared to Group I indicating cardiac toxicity. The increase in the levels of CK-MB and LDH enzymes after NaF intoxication was agreed with the results of Ibrahim and Abdel-Daim, 2013 [19]. No significant variation was found in the serum levels of CK-MB and LDH levels in ASP control (Group VI) when compared to Group I. Marked reduction in the serum levels of CK-MB and LDH was observed in a dose-dependent manner $(\mathrm{p}<0.001)$ after treatment with ASP in Groups III-V when compared to the Group II. All the values are summarized in Table 1.

\section{Effect on glucose and magnesium levels}

Increased blood serum glucose and decreased magnesium levels indicate diabetic properties of $\mathrm{NaF}$ intoxication [20,21]. Blood serum glucose and magnesium levels were presented in Table 2. Significant increases in serum glucose and decreased magnesium levels were observed in Group II $(\mathrm{p}<0.001)$ when compared to Group I. No significant variation was found in serum glucose and magnesium levels in Group VI when compared to the Group I. ASP treatment showed significant reduction in the serum glucose level and recovered magnesium levels in a dosedependent manner $(\mathrm{p}<0.001, \mathrm{p}<0.05)$ when compared to the Group II.

\section{Effect on lipid profile}

Significant changes occurred in lipid profile (TC, TG, and HDL-C) after chronic exposure with fluoride, and the results of this study matched with observations of the previous research report of Vasant et al., 2014 [22]. Increase in the serum cholesterol and TG levels and decrease in HDL-C were observed in Group II $(\mathrm{p}<0.001)$ when compared to Group I. Group VI showed decrease in the serum cholesterol and TGs levels $(p<0.01$ and $p<0.05)$ and a significant increase in the levels of HDL-C $(p<0.001)$. Treatment with ASP showed a significant decrease in the serum cholesterol and TG levels and increase in HDL-C level in a dose-dependent manner (Groups III-V) $(\mathrm{p}<0.001$ and $\mathrm{p}<0.05)$. All the values are presented in Table 2 .

\section{Effect on SGOT, SGPT, total and direct bilirubin, and total protein and albumin levels}

The earlier research studies are strongly reported that $\mathrm{NaF}$ intoxication enhanced lipid peroxidation and decreased levels of GSH and antioxidant enzymes which are directly reflected by altered serum liver biomarkers [1]. High intake of fluoride in Group II increased the blood

Table 1: Effect of ASP on serum CK-MB and LDH levels against NaF-induced cardiotoxicity

\begin{tabular}{lll}
\hline Name of the group & CK-MB (IU/L) & LDH (IU/L) \\
\hline Group I & $214.1 \pm 35.00$ & $282.2 \pm 15.51$ \\
Group II & $1214 \pm 12.95^{\mathrm{d}}$ & $1922 \pm 117.6^{\mathrm{d}}$ \\
Group III & $1100 \pm 28.63^{\text {ad }}$ & $1432 \pm 56.32^{\mathrm{d}}$ \\
Group IV & $846.8 \pm 48.11^{\text {ad }}$ & $1021 \pm 70.78^{\text {ad }}$ \\
Group V & $495.3 \pm 46.33^{\text {ad }}$ & $766.0 \pm 59.12^{\text {ad }}$ \\
Group VI & $165.4 \pm 12.04$ & $347.2 \pm 16.31$ \\
\hline
\end{tabular}

Values are represented as mean \pm standard error of mean. Statistical analysis performed using one-way analysis of variance followed by post hoc Dunnett's test. ${ }^{\mathrm{a}} \mathrm{p}<0.001$ versus NaF control; ${ }^{\mathrm{d}} \mathrm{p}<0.001$ versus normal control. NaF: Sodium fluoride, ASP: Arthrospira platensis, CK-MB: Creatine kinase-MB, LDH: Lactate dehydrogenase 
Table 2: Effect of ASP on serum glucose, magnesium, and lipid profile levels against NaF-induced hepatotoxicity

\begin{tabular}{|c|c|c|c|c|c|}
\hline Name of the group & Glucose (mg/dl) & Magnesium (mEq/L) & Cholesterol (mg/dl) & TG (mg/dl) & HDL-C (mg/dl) \\
\hline Group I & $100.70 \pm 2.34$ & $4.02 \pm 0.03$ & $99.17 \pm 3.82$ & $64.42 \pm 4.55$ & $31.05 \pm 0.80$ \\
\hline Group II & $131.50 \pm 6.88^{\mathrm{d}}$ & $2.11 \pm 0.02$ & $186.3 \pm 3.58^{d}$ & $88.10 \pm 1.99^{d}$ & $21.09 \pm 0.68$ \\
\hline Group III & $118.00 \pm 3.52^{c}$ & $3.18 \pm 0.15^{\mathrm{e}}$ & $169.5 \pm 2.28$ & $81.00 \pm 1.63$ & $25.40 \pm 0.89$ \\
\hline Group IV & $105.00 \pm 2.90^{\mathrm{a}}$ & $3.58 \pm 0.12$ & $140.3 \pm 5.03$ & $69.05 \pm 2.35^{\mathrm{a}}$ & $31.79 \pm 1.43$ \\
\hline Group V & $93.78 \pm 1.69^{a}$ & $3.84 \pm 0.17$ & $115.6 \pm 5.50$ & $65.38 \pm 2.354^{\mathrm{a}}$ & $49.78 \pm 3.05^{\mathrm{d}}$ \\
\hline Group VI & $88.09 \pm 2.79^{\mathrm{e}}$ & $4.19 \pm 0.28$ & $85.52 \pm 2.43$ & $52.56 \pm 1.28 \mathrm{e}$ & $57.10 \pm 2.23^{\mathrm{d}}$ \\
\hline
\end{tabular}

Values are represented as mean \pm standard error of mean, $\mathrm{n}=6$ in each group. Statistical analysis performed using one-way analysis of variance followed by post hoc Dunnett's multiple comparison test. ${ }^{\mathrm{a}} \mathrm{p}<0.001$ and ${ }^{\mathrm{c}} \mathrm{p}<0.05$ versus $\mathrm{NaF}$ control; ${ }^{\mathrm{d}} \mathrm{p}<0.001$ and ${ }^{\mathrm{e}} \mathrm{p}<0.01$ versus normal control. NaF: Sodium fluoride, ASP: Arthrospira platensis, TG: Triglycerides, HDL-C: High-density lipoprotein cholesterol

Table 3: Effect of ASP on liver serum biomarkers against sodium fluoride-induced hepatotoxicity

\begin{tabular}{|c|c|c|c|c|c|c|}
\hline $\begin{array}{l}\text { Name of } \\
\text { the group }\end{array}$ & SGOT (IU/ml) & SGPT (IU/ml) & Total bilirubin (mg/dl) & $\begin{array}{l}\text { Direct } \\
\text { bilirubin (mg/dl) }\end{array}$ & Total protein (mg/dl) & Albumin (g/dl) \\
\hline Group I & $31.71 \pm 1.71$ & $21.76 \pm 1.65$ & $1.25 \pm 0.048$ & $0.143 \pm 0.01$ & $7.92 \pm 0.15$ & $2.46 \pm 0.08$ \\
\hline Group II & $100.9 \pm 6.48^{d}$ & $109.9 \pm 11.43^{\mathrm{d}}$ & $4.04 \pm 0.19^{d}$ & $0.305 \pm 0.02$ & $6.39 \pm 0.18^{d}$ & $2.09 \pm 0.07$ \\
\hline Group III & $91.34 \pm 4.86^{\mathrm{d}}$ & $94.66 \pm 3.06^{d}$ & $3.46 \pm 0.13^{c d}$ & $0.287 \pm 0.01$ & $7.26 \pm 0.13^{c}$ & $2.59 \pm 0.16$ \\
\hline Group IV & $67.99 \pm 3.13^{\mathrm{ad}}$ & $68.02 \pm 3.73^{\mathrm{ad}}$ & $2.65 \pm 0.18^{\mathrm{ad}}$ & $0.217 \pm 0.08$ & $8.49 \pm 0.23^{a}$ & $3.84 \pm 0.26^{\mathrm{ad}}$ \\
\hline Group V & $43.73 \pm 3.53^{a}$ & $47.94 \pm 3.07$ & $1.74 \pm 0.27^{\mathrm{a}}$ & $0.173 \pm 0.05$ & $9.13 \pm 0.21^{\mathrm{ad}}$ & $4.86 \pm 0.10^{\mathrm{ad}}$ \\
\hline Group VI & $33.48 \pm 3.16$ & $40.47 \pm 1.68$ & $0.885 \pm 0.07$ & $0.155 \pm 0.08$ & $9.75 \pm 0.30^{d}$ & $4.78 \pm 0.26^{d}$ \\
\hline
\end{tabular}

Values are represented as mean \pm standard error of mean, $\mathrm{n}=6$ in each group. Statistical analysis performed using one-way analysis of variance followed by post hoc Dunnett's multiple comparison test. ${ }^{\mathrm{a}} \mathrm{p}<0.001$ and ${ }^{\mathrm{c}} \mathrm{p}<0.05$ versus NaF control; ${ }^{\mathrm{d}} \mathrm{p}<0.001$ versus normal control. NaF: Sodium fluoride, ASP: Arthrospira platensis, SGOT: Serum glutamic oxalocetic transaminase, SGPT: Serum glutamic-pyruvic transaminase

serum levels of SGOT, SGPT, direct and total bilirubin, and decrease the levels of total protein and albumin when compared to the Group I. Supplementation of ASP in Group VI did not show any significant impact in the serum SGOT, SGPT, direct and total bilirubin levels while significant increase in serum levels of total protein and albumin $(p<0.001)$ was observed when compared to Group I. Treatment with ASP showed significant recovery from SGOT, SGPT, direct and total bilirubin levels, and improved levels of protein and albumin in a dosedependent manner $(\mathrm{p}<0.001, \mathrm{p}<0.01$, and $\mathrm{p}<0.05)$ when compared to Group II. All the values are summarized in Table 3.

\section{Effect on serum BUN, uric acid, and creatinine levels}

The kidney is the major excretory organ for the confiscation of fluoride from the body. Numerous studies clearly showed that kidney has a close correlation between fluoride intake and renal injury [23]. Effect on serum BUN, uric acid, and creatinine levels were presented in Table 4. There was a significant increase in the serum BUN, uric acid, and creatinine in Group II $(p<0.001)$ when compared to Group I. Group VI showed a significant increase in serum levels of BUN and uric acid and no change in creatinine level. This might be due to its relative richness in protein and nucleic acid contents. Treatment with ASP showed an increase in the serum levels of BUN and uric acid, but decrease in the level of creatinine was observed $(\mathrm{p}<0.001)$ in a dose-dependent manner (Groups III-V) when compared to Group II.

\section{Effect on oxidative stress markers of heart, kidney, and liver}

Oxidative stress is a condition that indicates the imbalance between the prooxidants and antioxidants leading to the chemical injury to lipids, proteins, and DNA [15]. Excessive intake of fluoride also causes oxidative stress by induce the production of free radicals and decrease in biological activities of endogenous enzymatic and non-enzymatic antioxidant levels which play a central role in the elimination of free radicals and maintenance of antioxidant homeostasis. In addition, disturbs the metabolism of nucleic acids suppress the immune system, oxidation of macromolecules, membrane phospholipids breakdown, lipid peroxidation, and apoptosis. In this study, the administration of $\mathrm{NaF}$ in Group II $(\mathrm{p}<0.001)$ resulted in increased lipid peroxidation level with decrease in reduced glutathione and catalase levels of the heart, liver, and kidney. These findings have coincided with the results of
Table 4: Effect of ASP on serum BUN, uric acid, and creatinine levels against NaF-induced nephrotoxicity

\begin{tabular}{llll}
\hline $\begin{array}{l}\text { Name of } \\
\text { the group }\end{array}$ & BUN (mg/dl) & Uric acid (mg/dl) & Creatinine (mg/dl) \\
\hline Group I & $6.207 \pm 0.48$ & $1.01 \pm 0.73$ & $0.62 \pm 0.05$ \\
Group II & $15.15 \pm 0.84^{\mathrm{d}}$ & $1.99 \pm 0.02^{\mathrm{d}}$ & $1.45 \pm 0.06^{\mathrm{d}}$ \\
Group III & $16.47 \pm 0.76^{\mathrm{d}}$ & $1.59 \pm 0.08^{\mathrm{e}}$ & $1.052 \pm 0.08^{\text {ad }}$ \\
Group IV & $19.14 \pm 0.77^{\text {cd }}$ & $2.16 \pm 0.12^{\mathrm{d}}$ & $0.77 \pm 0.05^{\mathrm{a}}$ \\
Group V & $23.73 \pm 0.91^{\text {ad }}$ & $2.67 \pm 0.19^{\text {ad }}$ & $0.528 \pm 0.09^{\mathrm{a}}$ \\
Group VI & $24.80 \pm 2.23^{\mathrm{d}}$ & $2.733 \pm 0.20^{\mathrm{d}}$ & $0.54 \pm 0.04$ \\
\hline
\end{tabular}

Values are represented as mean \pm standard error of mean. Statistical analysis performed using one-way analysis of variance followed by post hoc Dunnett's test. ${ }^{a} p<0.001$ and ${ }^{c} p<0.05$ versus $\mathrm{NaF}$ control; ${ }^{d} \mathrm{p}<0.001$ and ${ }^{\mathrm{e}} \mathrm{p}<0.01$ versus normal control. ASP: Arthrospira platensis, BUN: Blood urea nitrogen, NaF: Sodium fluoride

earlier research reports $[5,24,25]$. Decreased level of lipid peroxidation and increased level of reduced glutathione $(\mathrm{p}<0.001)$ were observed in Group VI when compared to the Group I. Treatment with ASP showed significant recovery from lipid peroxidation and increased levels of reduced glutathione and catalase in a dose-dependent manner (Groups III-V) $(\mathrm{p}<0.001, \mathrm{p}<0.01$, and $\mathrm{p}<0.05)$ when compared to the Group II. All the values are presented in Table 5.

\section{CONCLUSION}

The present study suggesting that ASP was effectively alleviating the NaF-induced toxicity on soft tissues - heart, liver, and kidney. Further detailed studies are required to understand the exact mechanism involved in that. However, the present study was very useful and plays a significant additive role for the development of specific antidote against fluoride-induced intoxication

\section{ACKNOWLEDGMENT}

The authors are thankful to UGC, New Delhi, India, for research grants. We also gratefully acknowledge Dr. K. Abbulu, Principal, CMR College of Pharmacy, for his support in successful completion of the research work. 
Table 5: Effect of ASP on lipid peroxidation, reduced glutathione, and catalase against NaF-induced intoxication on soft tissues

\begin{tabular}{|c|c|c|c|c|c|c|c|c|c|}
\hline \multirow{2}{*}{$\begin{array}{l}\text { Name of } \\
\text { the group }\end{array}$} & \multicolumn{3}{|c|}{ Lipid peroxidation ( $\mu \mathrm{Mol} / \mathrm{mg}$ of tissue) } & \multicolumn{3}{|c|}{ Reduced glutathione ( $\mu \mathrm{Mol} / \mathrm{mg}$ of tissue) } & \multicolumn{3}{|c|}{ Catalase ( $\mu \mathrm{Mol} / \mathrm{mg}$ of tissue) } \\
\hline & Heart & Liver & Kidney & Heart & Liver & Kidney & Heart & Liver & Kidney \\
\hline & & & & & & & & & \\
\hline & 11 & .50 & & 35 & & & $=0.02$ & .02 & $=0.01$ \\
\hline Group III & $9.34 \pm 0.27^{\text {cd }}$ & $9.79 \pm 0.20$ & $9.288 \pm 0.22^{\mathrm{d}}$ & $7.235 \pm 0.61^{\mathrm{e}}$ & $7.33 \pm 0.33$ & $5.960 \pm 0.57$ & $0.200 \pm 0.02^{\mathrm{ad}}$ & $0.56 \pm 0.04^{\mathrm{f}}$ & $0.30 \pm 0.02$ \\
\hline & $6.46 \pm 0.34^{\mathrm{ae}}$ & $6.51 \pm$ & 6.685 & $66^{\mathrm{ad}}$ & $13.5 \pm 0.62^{\mathrm{a}}$ & $=0.76^{\mathrm{a}}$ & $0.368 \pm 0.02$ & $1.70 \pm 0.28^{\mathrm{af}}$ & $0.47 \pm 0.03^{b}$ \\
\hline Gro & $4.51 \pm 0.29^{\mathrm{a}}$ & $4.65 \pm$ & 3.810 & 21.56 & $18.8 \pm$ & $15.53 \pm 0.58^{\mathrm{a}}$ & $0.926 \pm 0.06^{\mathrm{ad}}$ & $2.90 \pm 0.12^{\text {ae }}$ & $0.71 \pm 0.04^{\mathrm{a}}$ \\
\hline Group VI & $2.83 \pm 0.30$ & $3.56 \pm 0.32$ & $3.303 \pm 0.27$ & $28.81 \pm 1.77$ & $19.7 \pm 0.76^{\mathrm{d}}$ & $17.75 \pm 0.75^{\mathrm{d}}$ & $1.47 \pm 0.19$ & $3.29 \pm 0.37^{\mathrm{d}}$ & $1.80 \pm 0.03$ \\
\hline
\end{tabular}

Values are represented as mean \pm standard error of mean, $\mathrm{n}=6$ in each. Statistical analysis performed using one-way analysis of variance followed by post hoc Dunnett's multiple comparison test. ${ }^{\mathrm{a}} \mathrm{p}<0.001$ and ${ }^{\mathrm{b}} \mathrm{p}<0.01$ versus $\mathrm{NaF}$ control; ${ }^{\mathrm{C}} \mathrm{p}<0.05$ (95\%); ${ }^{\mathrm{d}} \mathrm{p}<0.001,{ }^{\mathrm{e}} \mathrm{p}<0.01$, and ${ }^{\mathrm{f}} \mathrm{p}<0.05$ versus normal control. ASP: Arthrospira platensis, NaF: Sodium fluoride

\section{REFERENCES}

1. Hassan HA, Yousef MI. Mitigating effects of antioxidant properties of black berry juice on sodium fluoride induced hepatotoxicity and oxidative stress in rats. Food Chem Toxicol 2009;47(9):2332-7.

2. Ghosh A, Mukherjee K, Sumanta KG, Saha B. Sources and toxicity of fluoride in environment. Res Chem Intermed 2013;39(7):2881-915.

3. Amini M, Mueller K, Abbaspour KC, Rosenberg T, Afyuni M, Møller KN, et al. Statistical modeling of global geogenic fluoride contamination in groundwaters. Environ Sci Technol 2008;42(10):3662-8.

4. Ayoob S, Gupta AK. Fluoride in drinking Water: A review on status and stress effects. Crit Rev Environ Sci Technol 2006;36(6):433-87.

5. Vasant RA, Narasimhacharya AV. Amelioration of fluoride induced oxidative stress by Mangifera indica L. fruit. Spatula DD 2011;1(4):181-8

6. Emejulu AA, Alisi CS, Asiwe ES, Lgwe CU, Nwogu LA, Onwuliri VA. Renal and hepato-protective effects of Irvingia gabonensis juice on sodium fluoride-induced toxicity in wistar rats. J Clin Toxicol 2016;6(2):1-6.

7. Vasant RA, Narasimhacharya AV. Alleviatory effects of Emblica officinalis G. As a food supplement in fluoride induced hyperlipemia and oxidative stress. Int J Pharm Sci 2012;4(1):404-8.

8. El-Baz FK, El-Senousy WM, El-Sayed AB, Kamel MM. In vitro antiviral and antimicrobial activites of Spirulina platensis extract. J Appl Pharm Sci 2013;3(12):52-6.

9. Sharoud MN. Protective effect of Spirulina platensis against paracetamol induced hepatic injury in rats. J Exp Biol Agric Sci 2015;3(1):44-53

10. Karadeniz A, Yildirim A, Simsek N, Kalkan Y, Celebi F. Spirulina platensis protects against gentamicin-induced nephrotoxicity in rats. Phytother Res 2008;22(11):1506-10.

11. Ibrahim AE, Abdel-Daim MM. Modulating effects of Spirulina platensis against tilmicosin-induced cardiotoxicity in mice. Cell $\mathrm{J}$ 2015;17(1):137-44.

12. Balasubramanian V, Swetha B, Gayasuddin MD, Smreen S. Antiobesity activity of Spirulina platensis in high fat induced rats. Int J Pharmacol Screen Methods 2013;3(1):1-5

13. Maniyar R, Umashankar GK. Effectiveness of spirulina mouthwash on reduction of dental plaque and gingivitis: A clinical study. Int J Pharm
Pharm Sci 2017;9(7):136-9.

14. Raghavendra M, Reddy AM, Yadav PR, Raju AS, Kumar LS. Comparative studies on the in vitro antioxidant properties of methanolic leafy extracts from six edible leafy vegetables of India. Asian J Pharm Clin Res 2013;6(30):96-9.

15. Vasant RA, Narasimhacharya AV. Ameliorative effect of tamarind leaf on fluoride-induced metabolic alterations. Environ Health Prev Med 2012;17(6):484-93.

16. Claiborne A. In: Greenwald RA, editor. Handbook of Methods for Oxygen Radical Research. Boca Raton, FL: CRC Press; 1985. p. 283-4.

17. Jollow DJ, Mitchell JR, Zampaglione N, Gillette JR. Bromobenzeneinduced liver necrosis. Protective role of glutathione and evidence for 3,4-bromobenzene oxide as the hepatotoxic metabolite. Pharmacology 1974; 11(3):151-69.

18. Niehaus WG Jr, Samuelsson B. Formation of malonaldehyde from phospholipid arachidonate during microsomal lipid peroxidation. Eur J Biochem 1968;6(1):126-30.

19. Ibrahim AA, El-Khalek AM. Possible protective role of calcium against fluoride induced cardio toxicities in adult male albino rats. J Am Sci 2013;9(4):499-510.

20. Vasant RA, Narasimhacharya AV. Antihyperglycemic and antihyperlipidemic effects of Mangifera indica L. In fluoride induced toxicity. Phamacologyonline 2011;3:265-74.

21. Simmons D, Joshi S, Shaw J. Hypomagnesaemia is associated with diabetes: Not pre-diabetes, obesity or the metabolic syndrome. Diabetes Res Clin Pract 2010;87(2):261-6.

22. Vasant RA, Vincent ER, Karan SS, Narasimhacharya AL. Multigrain diet mitigates fluoride induced metabolic toxicity. J Environ Occup Sci 2014;3(1):25-30

23. Nabavi SF, Moghaddam AH, Eslami S, Nabavi SM. Protective effects of curcumin against sodium fluoride-induced toxicity in rat kidneys. Biol Trace Elem Res 2012;145(3):369-74.

24. Nabavi SF, Nabavi SM, Mirzaei M, Moghaddam AH. Protective effect of quercetin against sodium fluoride induced oxidative stress in rat's heart. Food Funct 2012;3(4):437-41.

25. Kobayashi CA, Leite AL, Silva TL, Santos LD, Nogueira FC, Oliveira RC, et al. Proteomic analysis of kidney in rats chronically exposed to fluoride. Chem Biol Interact 2009;180(2):305-11. 